\title{
Side Effects of Nitrification Inhibitors on Non Target Microbial Processes in Soils
}

\author{
Ferisman Tindaon ${ }^{1}$, Gero Benckiser ${ }^{2}$ and Johannes Carl Gottlieb Ottow ${ }^{2}$ \\ ${ }^{1}$ Department of Agroecotechnology, Faculty of Agriculture, Nommensen University Jl. Sutomo No. $4 \mathrm{~A}$ \\ Medan 20234 Indonesia, phone +62614522922, fax: +62614571426, \\ e-mail: Ferisman_Tindaon@yahoo.com. \\ ${ }_{2}^{2}$ Institute for Applied Microbiology, Justus Leibig University Heinrich-Buff-Ring 26-32, 35392 Gießen, \\ Germany, phone +49-641/99-37351,37352, fax +49-641/99-37359.
}

Received 10 June 2010 / accepted 26 October 2010

\begin{abstract}
Agricultural chemicals have been used extensively in modern agriculture and toxicological studies suggest a great potential for inducing undesirable effects on non target organisms. A model experiment was conducted in order to determine side effects of three nitrification inhibitors (NIs, 3,4dimethylpyrazolephosphate $=$ DMPP, 4-Chlormethylpyrazole phosphate $=$ CIMPP and dicyandiamide $=$ DCD) on non target microbial processes in soils. Side effects and dose response curve of three NIs were quantified under laboratory conditions using silty clay, loam and a sandy soils. Dehydrogenase, dimethylsulfoxide reductase as well as nitrogenase activity (NA) and potential denitrification capacity were measured as common and specific non target microbial processes. The influence of 51000 times the base concentration, dose response curves were examined, and no observable effect level = NOEL, as well as effective dose $\mathrm{ED}_{10}$ and $\mathrm{ED}_{50}(10 \%$ and $50 \%$ inhibition) were calculated. The NOEL for microbial non target processes were about 30-70 times higher than base concentration in all investigated soils. The potential denitrification capacity revealed to be the most sensitive parameter. CIMPP exhibited the strongest influence on the non target microbial processes in the three soils. The NOEL, $\mathrm{ED}_{10}$ and $\mathrm{ED}_{50}$ values were higher in clay than in loamy or sandy soil. The NIs was the most effective in sandy soils.
\end{abstract}

Keywords: microbial non target processes, nitrification inhibitors, soil enzymes

\section{INTRODUCTION}

Arable land is often amended with agrochemicals like fertilizers, pesticides and other substances to increase plant production, and such practices are an integral part of modern agriculture. Addition of nitrification inhibitors (NIs) to fertilizers have beneficial effect on reducing nitrate leaching and nitrous oxide emission and as a result increase plant growth. A series of studies reported by Di and Cameron over the past few years show a reduction of about $60 \%$ in $\mathrm{NO}_{3}$ - leaching, $70 \%$ in $\mathrm{N}_{2} \mathrm{O}$ emissions and an increase of more than $20 \%$ in pasture yield can be achieved ( $\mathrm{Di}$ and Cameron 2005, 2006; Di et al. 2007; Moir et al. 2007; Sahrawat 2004; Singh and Verma 2007). The use of nitrifications inhibitors expected will be able to control the microbial ammonium oxidation which convert ammonium to nitrate, decrease $\mathrm{N}$ leaching, improve efficiency of $\mathrm{N}$ use by crops and decrease

J Trop Soils, Vol. 16, No. 1, 2011: 7-16

ISSN 0852-257X the nitrous oxides emission. Thereby $\mathrm{N}$ use ecologically will be more efficient. Further, nitrification inhibitors use in agriculture should be recommended in low concentration and capable to control nitrate supply to crop so that avoid the excess of nitrate supply in soils. The nitrification inhibitors have the specific influence that is only inhibit the nitritation (oxidize the ammonia become the nitrite) and not for nitratation (oxidize the nitrite become the nitrate) so that accumulation can be avoid. The Inhibitor should be bacteriostatic and not a bakteriocide which killing certain microorganism in soils like Nitrosobacter spp, Nitrosococcus sp. Finally, that NI have no negative influence on common microbial activity which is non target in soils (Trenkel 1997; Pasda et al. 2001).

The assessment of microbial activity and the role of microorganisms in ecological systems, especially in response to environmental pollution, agrochemicals and cultivation, climatic factors, demand reliable methods for estimating microbial biomass and activity in soils are known, e.g. measurement of ATP contents, substrate induced respiration, dehydrogenase and dimethyl 
suflidoxide reductase (Alef 1995; Debus and Hund 1997; Engelen et al. 1998: Caldwell 2005, Ginafreda et al. 2005). Soil quality changes resulting from environmental pedoturbation or management practices have been assessed through the use of soil enzyme. One such enzymes is the dehydrogenase whose activity is considered an indicator of oxidative metabolism in soils and thus of the microbiological (Quilchano and Maranon 2002). It represents the intercellular flux of electron to oxygen due to the activity of several intercellular enzymes catalyzing the transfer of hydrogen and electron from one compound to another. Dehydrogenases are generally present in every upper later of soils, and essential components of enzyme systems of microorganisms. Dehydrogenase activity can therefore be used as measure of microbial activity in soils (Debus and Hund 1997; Engelen et al. 1998, Rasool and Reshi 2010). Side effects of agrochemicals use in environment can be measured by perceiving change of microbial population or with determining the microbial processes activity such as dehydrogenase and dimethylsulforeductase activities, denitrification and nitrogenase activity in soils (Stepniewska and Wolinska 2005; Stepniewska et al. 2007)

These standard methods have been recognized to know the side effects of chemicals use to environment which can be checked either in laboratory and also in the field. The NIs, in addition to other agrochemicals, is extensively used in agriculture practice for control of nitrogen supply, but it has the potential to affect the quality of soil, water and air, with attendant risk to humans, flora and fauna in soil. Because of their relationship to soil biology and rapid response to changes in soil management, soil enzymes are recognized as sensitive indicators of soil health and quality (Caldwell 2005). In fact, they have been related to soil physico-chemical characters (Amador et al. 1997), microbial community structure (Kourtev et al. 2002), and disturbance (Boerner et al. 2000). With respect to nitrification inhibitors, however, so little has been done in so few locations that broad generalizations can not be drawn. Thus, the present investigation was aimed to specifically focus on the effects of nitrification inhibitors at different application rates on some key enzyme activities involved in common and specific non target microbial processes in different type of soils such as a clayey, loamy and sandy soils which are commonly found in tropical agricultural soils. With this information, patterns and recommendations for the use of fertilizers containing nitrification inhibitors can be identified. In addition the NOEL, $\mathrm{ED}_{10}, \mathrm{ED}_{50^{-}}$ values were determined to evaluate the ecotoxicity of the three NIs.

\section{MATERIALS AND METHODS}

This model experiment was conducted in laboratory of Institute for Apllied Microbiology, Faculty of Agricultural Sciences and Ecology Management, Justus Leibig University, Giessen Germany. Two tropical soils samples were taken from Soil Experiment Station Institute for Agronomy and Plant Protection in Giessen and a tropical sandy soil from Agrochemical Experimental Station, Bayerische Acetylen Soda Fabrik (BASF, Limburgerhof, Germany). The respective soils were clasified as Typic Udorthent (clayey soil) Typic Kandiudult (clay and loamy soil), and Typic Paleudult (sandy soil) according to Soil Taxonomy (Soil Survey Staff 1999). These three experiment soil varied in their chemical and physical properties such as texture, $\mathrm{pH}, \mathrm{C}$-content (Table 1).

\section{Nitrification Inhibitors}

Three kind of NIs were applied: 3,4dimethylpyrazolephosphate=DMPP and 4Chlor-methylpyrazole phosphate $=$ CIMPP (Purity 99.9\% and $99.7 \%$ ) were produced by BASF AG, Ludwigshafen Germany. Dicyandiamid (DCD = Purity 96\%) was produced by SKW Trotsberg Ag. Germany. These three NIs were applied at recommendation rates $0.36 \mu \mathrm{g}$ DMPP, $0.25 \mu \mathrm{g}$ ClMPP and $10 \mu \mathrm{g} \mathrm{DCD} \mathrm{g}^{-1}$ dry soil. These rates were equal to that incorporated in $\mathrm{N}$-fertilizer for $90 \mathrm{~kg}$ $\mathrm{N} \mathrm{ha}^{-1}$. In addition to this recommendation rate, higher NIs concentrations were also included in the experimental set up so as to predict its likely side

Table 1. Chemical and Physical Properties of Experiment Soils.

\begin{tabular}{lccc}
\hline \multirow{2}{*}{$\begin{array}{l}\text { Soil } \\
\text { properties }\end{array}$} & Silty clay & Loam & Loamy sand \\
\cline { 2 - 4 } Total-C (\%) & 1.35 & 1.30 & 0.70 \\
C-org (\%) & 0.40 & 0.55 & 0.27 \\
Total N (\%) & 0.15 & 0.15 & 0.08 \\
Ratio C/N & 10 & 9 & 9 \\
pH $\left(\mathrm{H}_{2} \mathrm{O}\right)$ & 6.30 & 7.00 & 7.00 \\
pH $(\mathrm{KCl})$ & 6.00 & 5.50 & 6.40 \\
Fraction $(\%)$ & & & \\
Clay & 51 & 24 & 6 \\
Loam & 41 & 46 & 19 \\
Sand & 8 & 30 & 75 \\
\hline
\end{tabular}


effects on microbial non target processes in the events its excessive use. The application rates used in the present study included 1, 5, 10, 25, 50, 100, 250, 500 and 1000 times of base concentrations.

\section{Soil Microbial Enzyme Assays}

Dehydrogenase activity (DHA) as an index of microbial activity was determined according to Alef (1995) using 2-p-iodophenyl-3-p-nitrophenyl-5phenyltetrazolium chloride (INT) as substrate and by spectrophotomectric quantification of produced formazan. The method relies on the reduction of INT by microorganisms to IodonitrotetrazoliumFormazan (INF). The concentration of INF was measured on a spectrophotometer (Fa Zeiss PM2DL) at $436 \mathrm{~nm}$ by using methanol as blank.

Dimethylsulfoxide reductase activity (DRA) was assayed according to Alef and Kleiner (1989) using Dimethylsulfoxide (DMSO). The determination of the DMSO reduction rate exploits the common microbial activity to reduce DMSO to DMS, proven nearly 150 species of bacteria and fungi. The concentrations of DMS was measured on a gas chromatography (Perkin Elmer 8500 equipped with flame-ionization detectors $=$ FID) and a 2.0 m column Hayesep R 1/8, 80-100 mesh. The column was operated at $160^{\circ} \mathrm{C}$, and the detector was operated at $220^{\circ} \mathrm{C}$. The flow rate of carrier gas, $\mathrm{N} 2$, was $35 \mathrm{ml} \mathrm{N} / \mathrm{min}$.

Potential denitrification capacity (PDC) was measured in four replications according to method of Pell et al. (1998). Thawed soil samples (40 g) were placed in 2 liters flasks and kept at room temperature overnight. On the following day, $20 \mathrm{ml}$ of substrate with $1 \mathrm{mM}$ glucose and $1 \mathrm{mM} \mathrm{KNO}_{3}$ was added and denitrifying conditions were achieved by evacuating and filling flasks with nitrogen gas five times. It takes time about 2-3 minutes. Acetylene was added to reach 0.1 atm partial pressure. The presence of acetylene that blocked up the $\mathrm{N}_{2} \mathrm{O}$ - reductase specifically can be measured as potential denitrification capacity. The soil was incubated at $25^{\circ} \mathrm{C}$ in a dark room for $6 \mathrm{~h}$, and gas samples were collected every one hour. Nitrous oxide in the gas samples was analyzed on a gas chromatograph (Perkin Elmer 8500 equipped with a flame-ionization detector and a $2.0 \mathrm{~m}$ column Hayesep R 1/8, 80-100 mesh). The column was operated at $160^{\circ} \mathrm{C}$, and the detector was operated at $220^{\circ} \mathrm{C}$. The flow rate of carrier gas, $\mathrm{N}_{2}$, was $35 \mathrm{ml}$ $\mathrm{N}_{2} /$ min.

Nitrogenase activity was determined with the method outlined by Martensson (1993) and modified by Chalam et al. (1997). Analysis for acetylene was performed with Perkin Elmer gas chromatograph (Perkin Elmer 8500 equipped electron capture detectors $=\mathrm{ECD}$ ) and a $2.0 \mathrm{~m}$ column Porapak Q. 1/8 80-100 mesh. The column was operated at $50^{\circ} \mathrm{C}$, and the detector was operated at $350^{\circ} \mathrm{C}$. The flow rate of carrier gas, $\mathrm{N}_{2}$, was 30 $\mathrm{ml} \mathrm{N} / \mathrm{min}$.

\section{Statistical Analysis}

Non linear regression analysis to drive ecotoxicological value were conducted on untransformed data from assays based on the concentration-response relationship for quantitative endpoint data, using regression model described in Stephenson et al. (2000). Analysis of variance (ANOVA) and Fisher's least significant difference pair wise comparison tests were applied to litter mass loss and enzymatic activity data for NOEL, $\mathrm{ED}_{10}$ and $\mathrm{ED}_{50}$ determinations. Differences were considered to be significant at a probability level of $\mathrm{P}<0.05$. Statistical analyses were performed using Sigma Plot and Sigma Stat Software.

\section{RESULTS AND DISCUSSION}

\section{Dose Response Relationships}

Mathematical model for ecotoxicological test on the NOEL, ED10 and ED50 for the three NIs data can be studied constructively by using Sigma plot and Sigma stat. So that approach method showed the threshold of ecotoxocological parameters the substances were determinable (Table 2 ). If using ordinary linear equation regression hence determination assess the NOEL from measurement data was not at all enabled. For example, a semilogaritmic dose response relationship between three NIs (DMPP, CIMPP, DCD) and dehydrogenase activity in clay soil presented in Figure 1. By using the equation for dose response curve (Richter et al. 1996) in Sigma Plot Program where as where as:

$$
\mathrm{Y}=\mathrm{a} /\left(1+\exp \left(-\left(\mathrm{X}_{\mathrm{t}}-\mathrm{X}_{0}\right) / \mathrm{b}\right)\right)
$$

it is posible to calculate critical value for NOEL, $\mathrm{ED}_{10}$ and $\mathrm{ED}_{50} . \mathrm{Y}=$ response, $\mathrm{a}$ for the maximum response, $\mathrm{Xo}$ and $\mathrm{Xt}=\log$ dose of used NIs according to time and $b$ for a constant of the NIinfluence.

\section{Dehydrogenase Activity (DHA)}

Figure 1 and 2, shows that the effect of increasing concentrations of the NIs on dehydrogenase activity in clayey soil occur if DMPP and CIMPP used in 50 times of the recommended dose. These were equivalent to $18 \mu \mathrm{g}$ DMPP, 6.3 


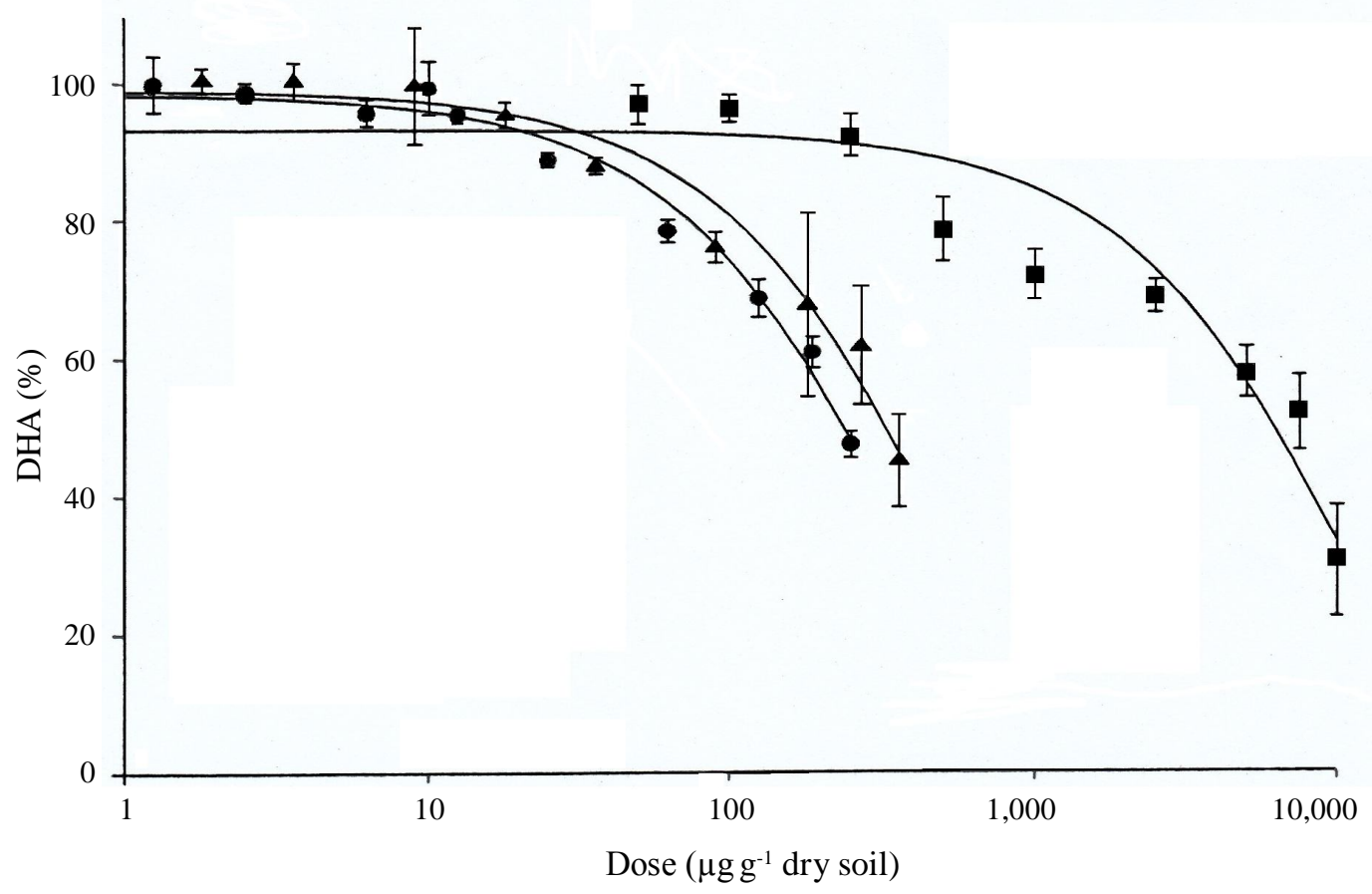

Figure 1. The effect of increasing application rates of NIs DMPP, CIMPP and DCD on dehyrogenase activity (\% control) in clayey soil (semilogaritmic, the dose in the log). Dosage recommendations, were $0.36 \mu \mathrm{g}$ DMPP; $0.25 \mu \mathrm{g}$ ClMPP and $10 \mu \mathrm{g}$ DCD per gram dry soil. $\Delta=\mathrm{DMPP}, \bullet=\mathrm{CMPP}, \boldsymbol{\square}=\mathrm{DCD}$.

$\mu \mathrm{g}$ ClMPP per gram of dry soil. While the new DCD visible effects occured if used as many as $250 \mu \mathrm{g}$ DCD per gram of soil. Based on absolute doses, it can be concluded that the NOEL values of three NIs for dehydrogenase activity is $18 \mu \mathrm{g}$ DMP, 6.3 $\mu \mathrm{g}$ and $250 \mu \mathrm{g}$ ClMPP DCD per gram of soil. Therefore the application of these inhibitors in corporated in $\mathrm{N}$ - fertilizer on recommended dose which equivalent to $90 \mathrm{~kg} \mathrm{~N}$ per hectare did not affect dehydrogenase activity in clayey soils.

A comparison with clayey soil (Figure 3 ) shows that DMPP, CIMPP and DCD inhibited the DHA at 25 times of base concentrations. The NOEL values in clay are $6 \mu \mathrm{g}$ ClMPP, $9 \mu \mathrm{g}$ DMPP and $250 \mu \mathrm{g}$ $\mathrm{DCD} \mathrm{g}^{-1}$ dry soil. It appears that the inhibitory effects of individual NI on general non target microbial activities are significantly larger in clayey soil (Figures 2 and 3). Even in sandy soil (Figure 5) the DHA was less affected. NOEL values for DHA in clay soils is $3.6 \mu \mathrm{g}$ DMPP; 2.5 and $100 \mu \mathrm{g}$ DCD CIMPP $\mu$ g per gram of soil. It turned out that in sandy soil inhibitory effect occurred faster and at lower concentrations. Ecotoxicity of CIMPP was greater than DMPP and DCD, and more effective in inhibiting DHA in sandy soil than clay soil and clay.

\section{Dimethylsulfoxide Reductase Activity (DRA)}

The effect of increasing the three NIconcentrations on dimethylsulfoxide reductase activity on clay, loam and sandy soils shown in Figure 3, 4 and 5). Almost similar to the dehydrogenase activity, which the effect of inhibitor on DRA occurred at 25 times the recommended dose. It equals to $9.0 \mu \mathrm{g}$ DMPP: $6.3 \mu \mathrm{g}$ ClMPP whereas DCD at $100 \mu \mathrm{g}$ DCD per gram of dry soil. On loamy and sandy soils, the side effect of the three NIs appear at lower concentrations i.e. 3.6 $\mu \mathrm{g}$ DMPP: $2.5 \mu \mathrm{g}$ CIMPP and $100 \mu \mathrm{g}$ DCD per gram of dry soil. So it was obvious that DCD provides a smaller effect on DRA activity if compared to DMPP and CIMPP.

\section{Potential Denitrification Capacity}

Effect of various concentrations of inhibitors nitrifications on denitrification potential capacity has been occurred clearly at 50 times of the recommended dose on clayey soil, and 10 times of recommended dose on loamy and sandy soils. When it compared with the DHA and DRA, the denitrification is more sensitive to all three of these inhibitors. This can be caused by inhibition of nitrate formation by the three inhibitors, because it found that nitrate levels in soils that treated with inhibitors are not much different from the control (separate experiments).

\section{Nitrogenase Activity}

The use of three nitrification inhibitors DMPP,CIMPP and DCD had no significant effect 
(a)
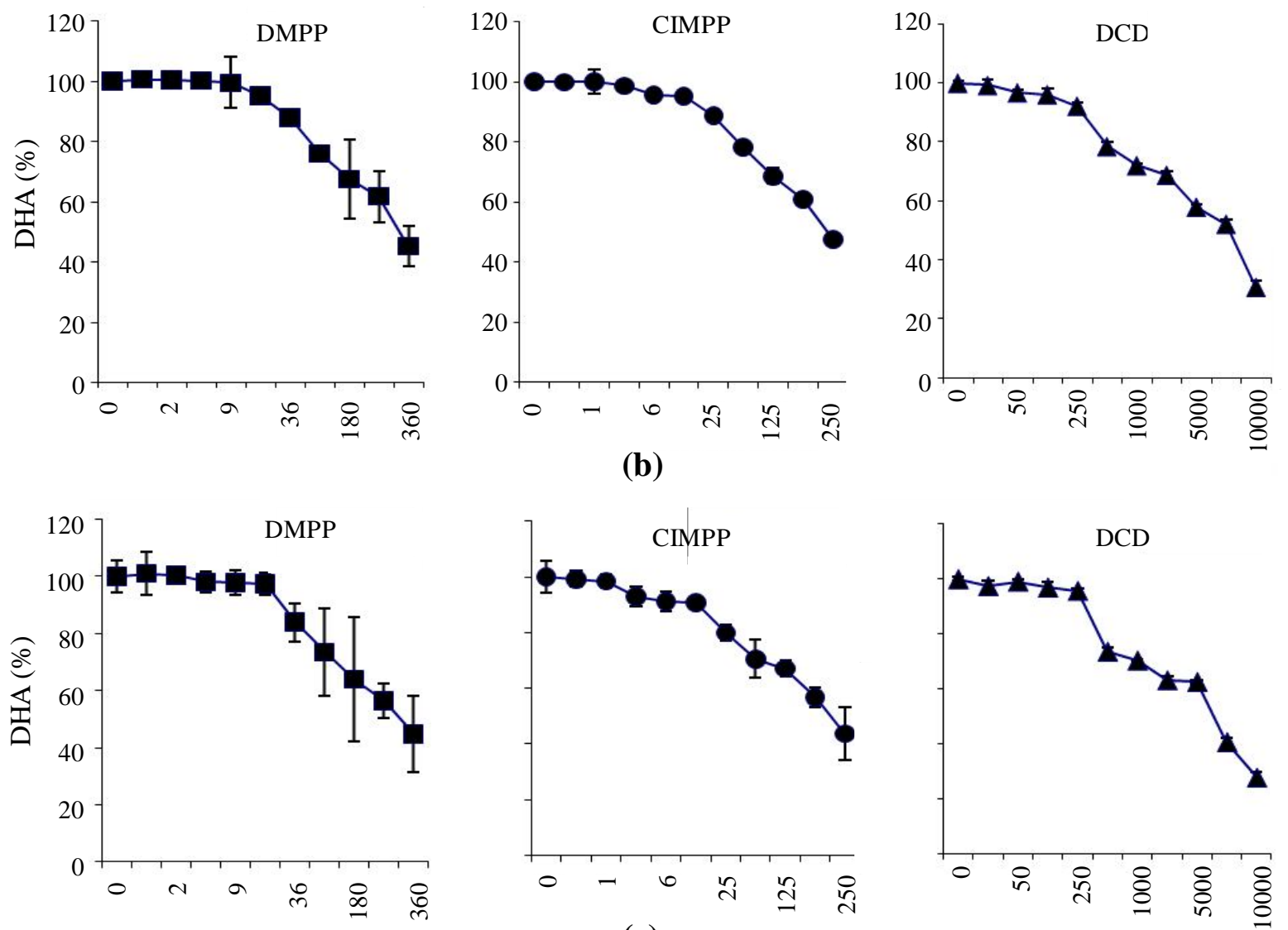

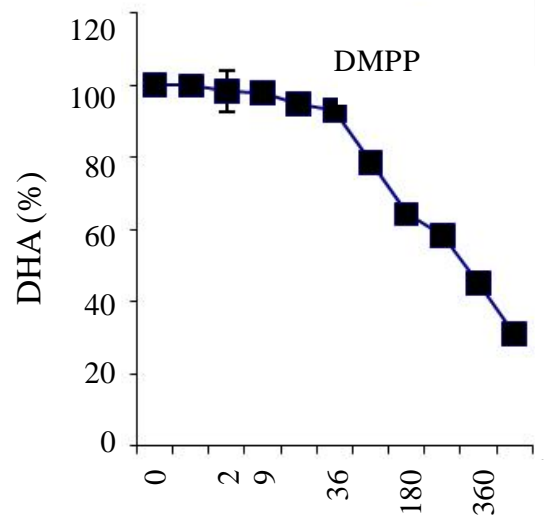

Dose ( $\mu \mathrm{g}^{-1}$ dry soil) (c)

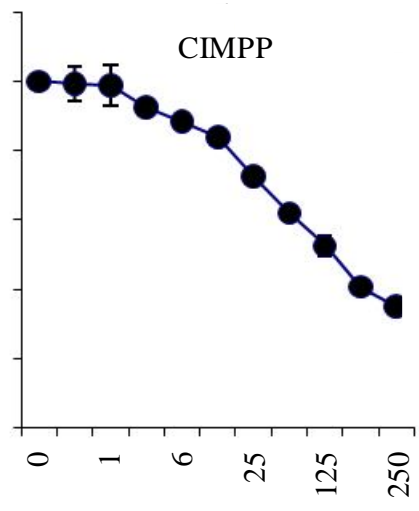

Dose $\left(\mu \mathrm{g}^{-1}\right.$ dry soil $)$

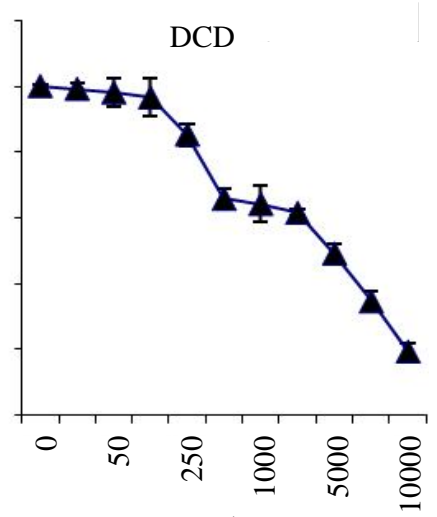

Dose ( $\mu \mathrm{g}^{-1}$ dry soil)

Figure 2. The effect of increasing application rates of NIs DMPP, CIMPP and DCD on the dehydrogenase activity (DHA in \% control) in clayey soil (a), loamy soil (b) and sandy soil (c). Recommendation dosages were $0.36 \mu \mathrm{g}$ DMPP; $0.25 \mu \mathrm{g}$ ClMPP; and $10 \mu \mathrm{g} \mathrm{DCD} \mathrm{g}^{-1}$ dry soil.

on nitrogenase activity in the three soil types. So that the NOEL, $\mathrm{ED}_{10}$ and $\mathrm{ED}_{50}$ values cannot furtherly be determined. This was considered as positive thing, that the inhibitors do not reduce the activity of nitrogen fixing microorganisms both symbiotic and non symbiotic that was beneficial for plant $\mathrm{N}$ availability. Therefore, the study NOEL, $\mathrm{ED}_{10}$ and $\mathrm{ED}_{50}$ for the nitrogenase activity (NA) parameter is no longer presented in Table 2.
Generally, there is no clear toxicity difference between each nitrification inhibitors, due to NOEL, ED10 and ED50-values. Based on response average values, it can be concluded that CIMPP has more potential side effect on the activities of non target microbes in the soil. This is apparently caused by the effect of halogen element, like chlor, that effectively affects the microbial activity in the soil (Mc Carty 1999). Based on the NOEL value, the use of these inhibitors on the dose of 100 times of 
(a)
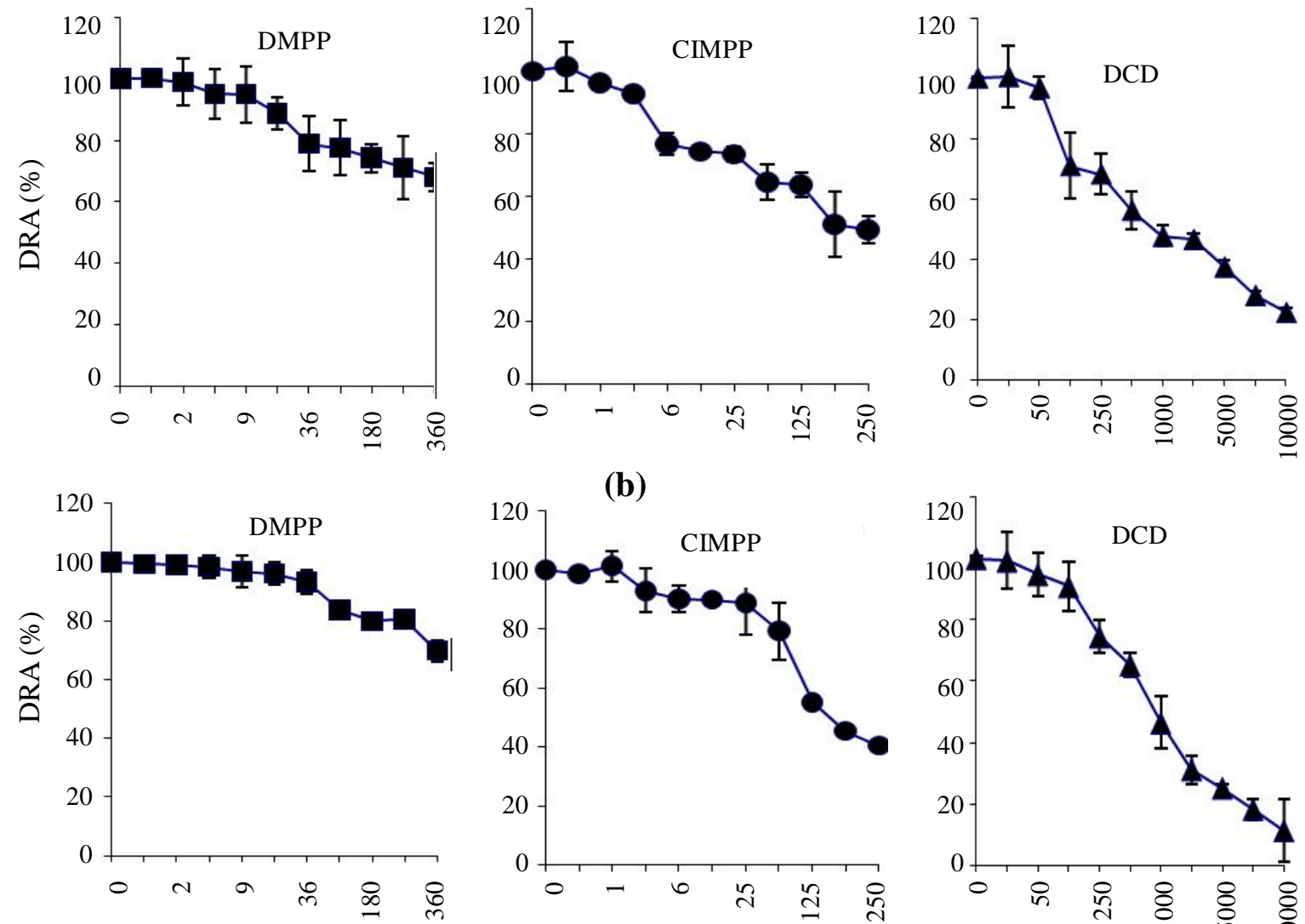

(b)
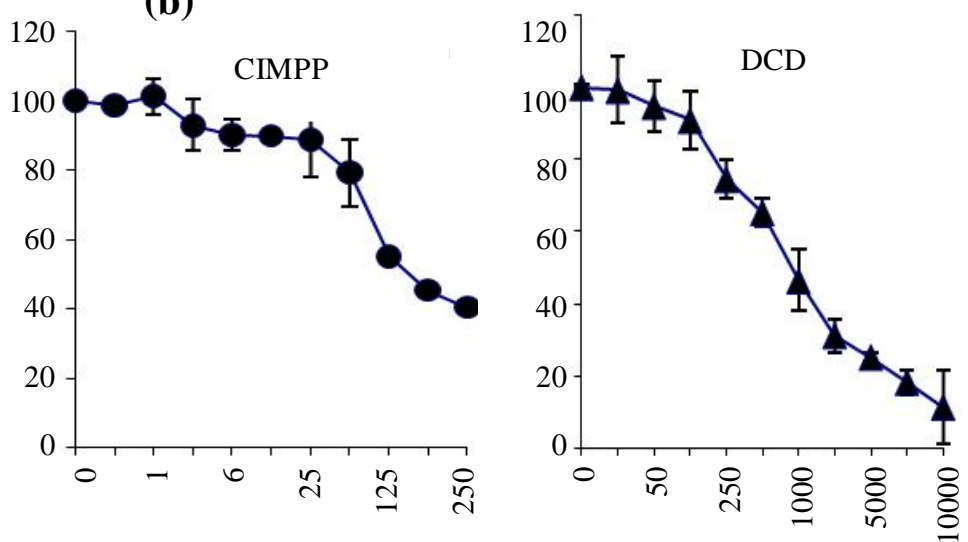

(c)

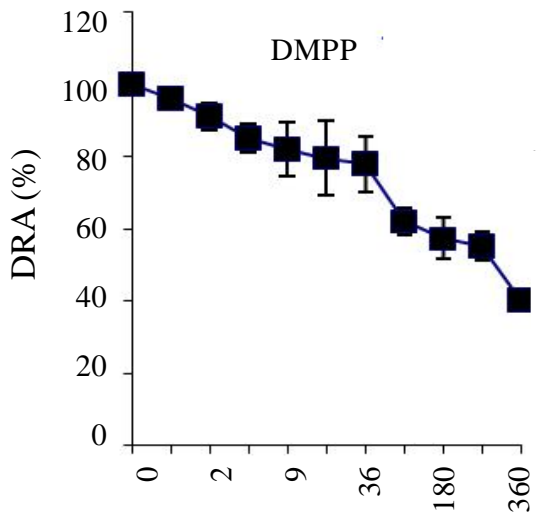

Dose ( $\mu \mathrm{g}^{-1}$ dry soil)

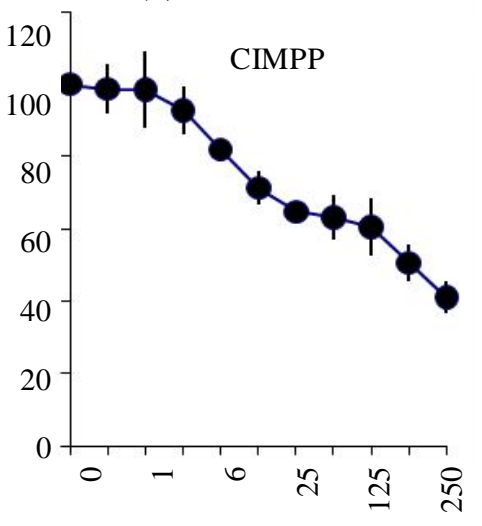

Dose $\left(\mu \mathrm{g}^{-1}\right.$ dry soil $)$

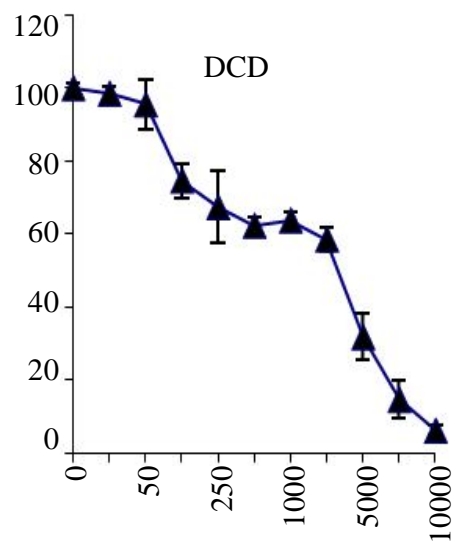

Dose $\left(\mu \mathrm{g}^{-1}\right.$ dry soil $)$

Figure 3. The effect of increasing application rates of NIs DMPP, CIMPP and DCD on dimethylsulfoxide reductase activity (DRA in \% control) in clayey soil (a), loamy soil (b) and sandy soil (c). Recommendation dosage were $0.36 \mu \mathrm{g}$ DMPP; $0.25 \mu \mathrm{g}$ ClMPP; and 10ìg DCD g ${ }^{-1}$ dry soil.

the recommended dose did not negatively affect the soil environment. All three inhibitors affected non target microbial activities in sandy soils more effectively than in loamy or clayey soils. This is due to the influence of soil clay fraction content that plays a role in adsorption mechanism of inhibitors on the clay surface (Azam et al. 2001; Barth et al. 2001). Once the nitrification inhibitor is in the soil, it is gradually broken down by soil microbes, thus diminishing its effectiveness. The degradation rate of DCD was affected by temperature (Irigoyen et al. 2003; Di and Cameron 2004; Singh and Verma 2007). When applied as solution, increasing DMPP concentrations up to 7 mg DMPP $\mathrm{kg}^{-1}$ soil had no influence on the inhibition. The effectiveness of DMPP formulated as fertilizer granules was superior to the liquid application of DMPP and $\mathrm{NH}_{4}^{+}$, particularly in the loamy soil. Without DMPP, a decline in soil matrix potential down to $-600 \mathrm{kPa}$ decreased nitrification in both soils, but this effect was more pronounced in the sandy loam than in the loamy soil. DMPP 


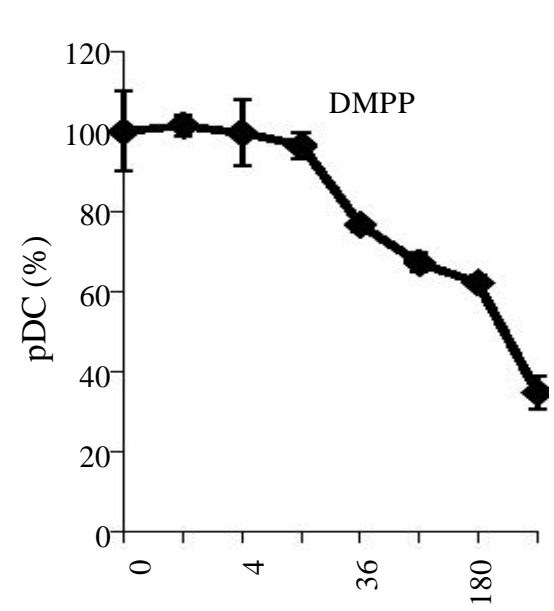

(a)
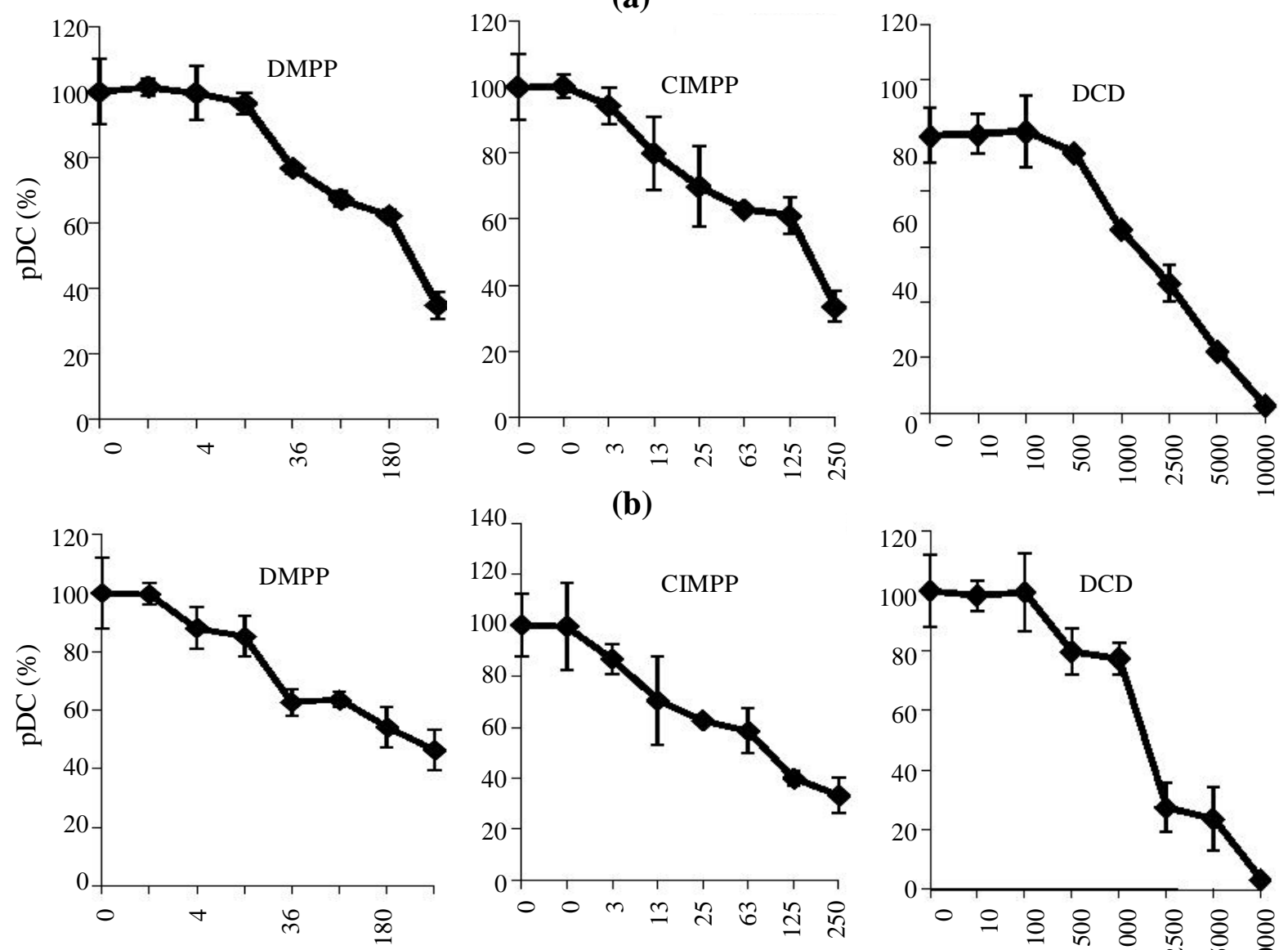

(b)
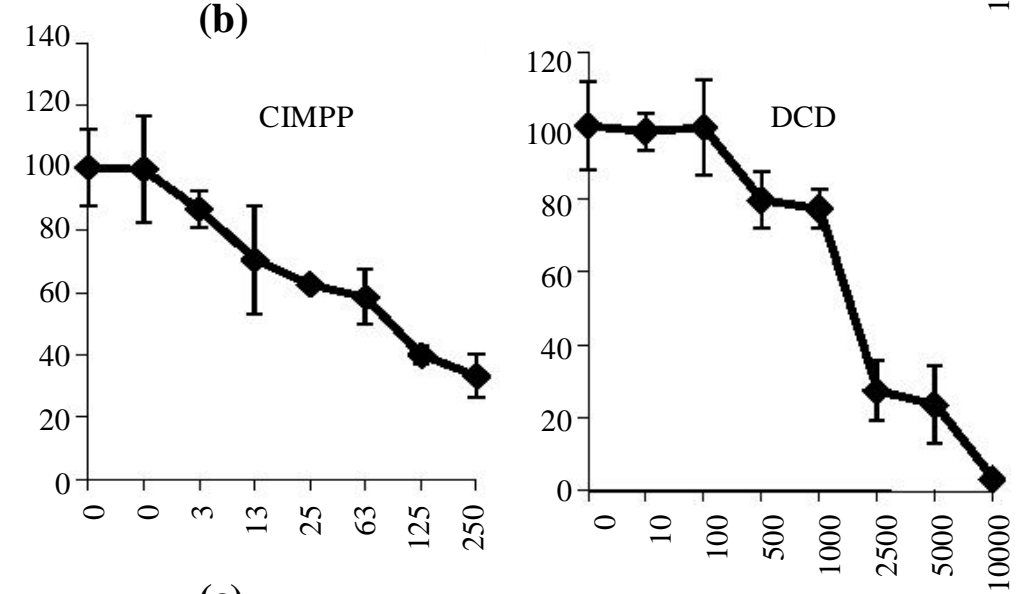

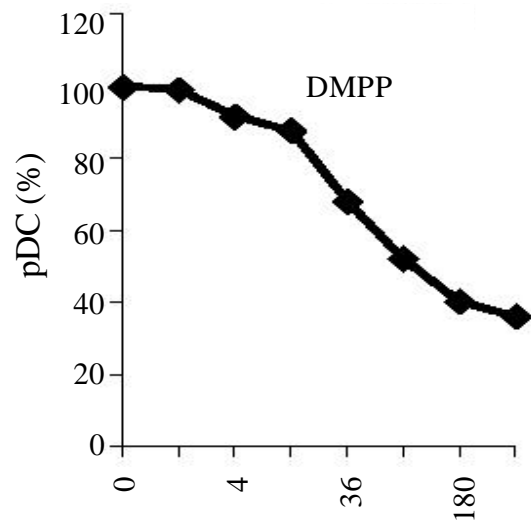

Dose $\left(\mu \mathrm{g}^{-1}\right.$ dry soil $)$

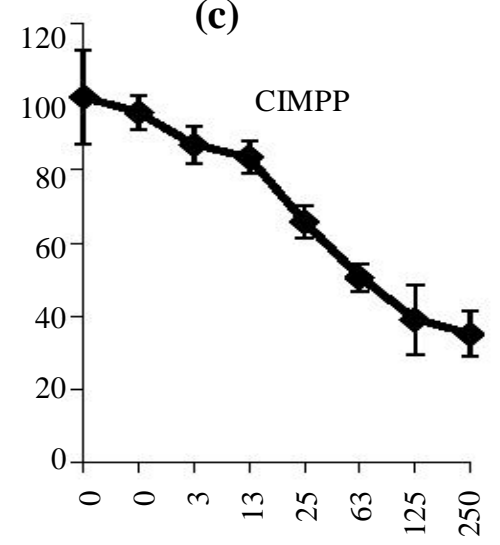

Dose ( $\mu \mathrm{g}^{-1}$ dry soil)

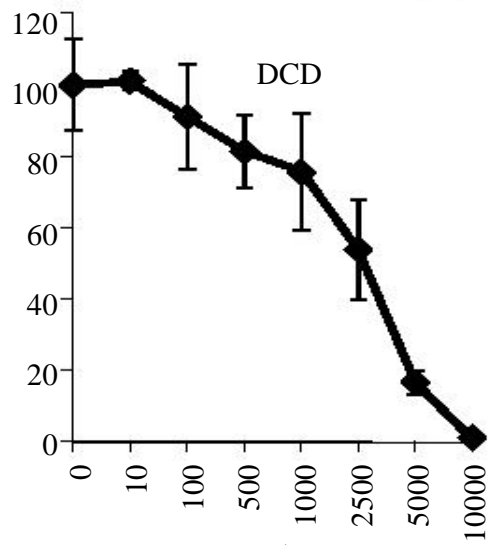

Dose $\left(\mu \mathrm{g}^{-1}\right.$ dry soil $)$

Figure 4. The effect of increasing application rates of NIs DMPP, CIMPP and DCD on potential denitrification capacity (PDC in \% control) in clayey soil (a), loamy soil (b) and sandy soil (c). Recommendation dosage were $0.36 \mu \mathrm{g}$ DMPP; $0.25 \mu \mathrm{g}$ ClMPP and $10 \mu \mathrm{g} \mathrm{DCD} \mathrm{g}^{-1}$ dry soil

was most effective in the sandy loam particularly under conditions of higher soil moisture, i.e., under conditions favorable for nitrate leaching (Hua Li et al. 2008). However, performance of NIs is highly variable in different agroecosystems as their persistence and activity is strongly influenced by various environmental factors. Adsorption of NIs on soil colloids can particularly reduce their effectiveness in inhibiting nitrification in soil, and this is well documented for the most widely used inhibitor viz., nitrapyrin. In addition, increasing temperatures significantly reduce the persistence of these inhibitors in soil and this is well established for DCD and DMPP (Irigoyen et al. 2003; Di and Cameron 2004).For the vulnerability (sensitive) level of various non-target microbial activity in the soil, it can be sorted that denitrification was more sensitive than dehydrogenase and dimethylsulfoxide reduction $($ PDC > DRA > DHA, Table 2). Environmental risk threshold value was studied 
Table 2. Ecotoxicological criteria of NOEL, $\mathrm{ED}_{10}$ and $\mathrm{ED}_{50}$ for evaluating the inhibitor effects of NIs on non-target activity of microorganism (DHA, DRA and PDC) in 3 predominant soils.

\begin{tabular}{|c|c|c|c|c|c|c|c|c|c|c|}
\hline \multirow[b]{2}{*}{ Parametres } & \multirow[b]{2}{*}{ Soil types } & \multicolumn{9}{|c|}{ 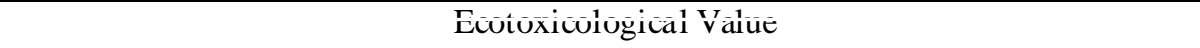 } \\
\hline & & $\begin{array}{l}\text { DMPP } \\
\text { NOEL }\end{array}$ & $\mathrm{ED}_{10}$ & ED50 & $\begin{array}{l}\text { ClMPP } \\
\text { NOEL }\end{array}$ & $\mathrm{ED}_{10}$ & $\mathrm{ED}_{50}$ & $\begin{array}{l}\text { DCD } \\
\text { NOEL }\end{array}$ & $\mathrm{ED}_{10}$ & $\mathrm{ED}_{50}$ \\
\hline \multirow[t]{4}{*}{ DHA } & Clay & 91 & 133 & 371 & 32 & 66 & 255 & 844 & 1754 & 6940 \\
\hline & Loam & 30 & 72 & 312 & 28 & 58 & 229 & 550 & 1126 & 5558 \\
\hline & Sand & 25 & 56 & 230 & 12 & 33 & 147 & 167 & 809 & 4450 \\
\hline & $\varnothing$ & 49 & 87 & 304 & 24 & 52 & 210 & 520 & 1230 & 5649 \\
\hline \multirow[t]{4}{*}{ DRA } & Clay & 47 & 101 & 365 & 27 & 55 & 215 & 395 & 1083 & 4965 \\
\hline & Loam & 11 & 53 & 287 & 19 & 48 & 197 & 296 & 1102 & 4533 \\
\hline & Sand & 5 & 44 & 266 & 4 & 15 & 133 & 112 & 402 & 2597 \\
\hline & $\varnothing$ & 24 & 66 & 306 & 17 & 39 & 182 & 268 & 862 & 4032 \\
\hline \multirow[t]{4}{*}{ PDC } & Clay & 30 & 62 & 241 & 7 & 29 & 155 & 366 & 761 & 2438 \\
\hline & Loam & 17 & 35 & 193 & 6 & 12 & 105 & 299 & 646 & 2049 \\
\hline & Sand & 5 & 17 & 150 & 2 & 11 & 98 & 159 & 487 & 1724 \\
\hline & $\varnothing$ & 17 & 38 & 195 & 5 & 17 & 119 & 275 & 631 & 2070 \\
\hline \multirow[t]{4}{*}{$\varnothing$} & Clay & 59 & 99 & 326 & 22 & 50 & 208 & 535 & 1199 & 4781 \\
\hline & Loam & 19 & 53 & 264 & 18 & 39 & 177 & 382 & 598 & 4047 \\
\hline & Sand & 12 & 39 & 215 & 6 & 20 & 126 & 146 & 566 & 2924 \\
\hline & $\emptyset^{1}$ & 30 & 64 & 268 & 15 & 36 & 170 & 354 & 908 & 3917 \\
\hline
\end{tabular}

Note: $\varnothing=$ Average of every non-target DHA, DRA, and PDK on each soil typw; $\varnothing^{1}=$ Average of non-target DHA, DRA, and PDK on three soil types.

based on USEPA equation (1984), that for laboratory trials the average NOEL-value was divided by 10 and for field trials the average NOEL value was divided by 100 (Table 2). It turned out that the environmental risk threshold value is still far above the value of 1-50 times $\mathrm{N}$ fertilizer recommended dose (inhibitor incorporated with $\mathrm{N}$ fertilizer). The current recommended rate for DCD is $10 \mathrm{~kg} \mathrm{DCD} \mathrm{ha-1}$ per application (Di and Cameron 2005), and DMPP was applied as the commercial product Urea with ENTECTM $(1.84 \mathrm{~kg}$ DMPP active ingredient $\mathrm{Mg}^{-1}$ urea or $0.71 \mu \mathrm{g}$ DMPP $\mathrm{g}^{-1}$ soil (Barth 2006; 2008). Later, CIMPP was not recommended to be used in agriculture practices. This means that the use of these three inhibitors is environmentally compatible and safe.

\section{CONCLUSIONS}

The dose response-curves for DHA, DRA and PDC were generally of sigmoid nature in all investigated soils. The dose response curves recorded suggest that DMPP, CIMPP and DCD may affect non target microbial soil processes only at high concentrations. In general, no side effects of the NIs on parameters DHA, DRA, PDC and NA were observed if rates about 70-90 times the base concentrations, corresponding to $17 \mu \mathrm{g}$ ClMPP, $30 \mu \mathrm{g}$ DMPP and $900 \mu \mathrm{g}$ DCD $\mathrm{g}^{-1}$ dry soil were applied (NOEL-value).The PDC revealed to be the most sensitive parameter. Sensitivity of three NIs in question decreased in the order of PDC $>$ DRA $>$ DHA > NA. Generally, ClMPP exhibited the strongest influence on non target microbial processes in the three soils compared to DMPP and DCD. Dose response relationships between NIs and microbial non target activities depend on soil types. The NOEL, $\mathrm{ED}_{10}$ and $\mathrm{ED}_{50}$-values were much higher in clay than in loamy sand or sandy soil. The NIs was generally the most effective in sandy soils. In conclusion, there are no negative effects of CIMPP, DMPP and DCD on soil micro flora and soil metabolism at recommended base concentration.

\section{ACKNOWLEDGEMENTS}

We thanks to PD Dr. G. Benckiser, Prof. Dr. J.C.G. Ottow in Institut for Applied Microbiology, University of Giessen, Germany for helping and supporting the experiment works. Special thanks we express to DAAD (Deutscher Akademischer Austauschdienst) in Bonn for providing the financial support. 


\section{REFERENCES}

Alef K and Kleiner D. 1989. Rapid and sensitive dtermination of microbial activity ini soils and in soil aggregates by dimethylsulfoxide reduction. Biol Fertil Soils 8: 349-355.

Alef K. 1995. Dehydrogenase activity. In: Alef and P Nanniperi (eds). Methods in applied soil microbiology and biochemistry. Academic Press. London pp, 228-231.

Amador JA, AM Glucksman, JB Lyons and JH Gorres. 1997. Spatial distribution of soil phosphatase activity within a riparian forest. Soil Sci 162: 808825.

Azam F, G Benckiser, C Muller and JCG Ottow. 2001. Release, movement and recovery of 3-4 dimethylpyrazole phosphate (DMPP), ammonium and nitrate from stabilized fertilizer granules in a silty clay soil under laboratory conditions. Biol Fertil Soils 34: 118-125.

Barth G. 2008. Effectiveness of 3,4-Dimethylpyrazole phosphate as nitrification inhibitor in soil as influenced by inhibitor concentration, application form, and soil matric potential. Pedosphere 18: 378-385.

Barth G, S von Tucher, S von und U Schmidhalter. 2001. Influence of soil parameter on the effects of 3-4 dimethylpyrazole phosphate (DMPP) as nitrification inhibitor. Biol Fertil Soils 34: 98102.

Barth G. 2006. Influence of soil properties on the effect of 3,4 - dimethylpyrazole - phosphate as nitrification inhibitor. Technischen Universität München.

Boerner REJ, KLM Decker and EK Sutherland. 2000. Prescribed burning effects on soil enzyme activity in a southern Ohio hardwood forest: a landscapescale analysis. Soil Biol Biochem 32: 899-908.

Caldwell BA. 2005. Enzyme activities as a component of soil biodiversity: A review. Pedobiologia 49: 637- 644.

Chalam AV, C Sasikala, CV Ramana, NR Uma and PR Rao. 1997. Effect of pesticide on diazotrophic growth and nitrogenase activity of purple non sulfur bacteria. Bull Environ Contam Toxicol 58: 463-468.

Debus R and K Hund. 1997. Development of analytical methods for assessment of ecotoxicological relevant soil contamination: Part B - Ecotoxicological Analysis in Soil and Soil Extracts. Chemosphere 35: 239-261. DOI: 10.1007/BF02991039.

Di HJ and KC Cameron. 2004. Effects of temperature and application rate of a nitrification inhibitor, dicyandiamide (DCD) on nitrification rate and microbial biomass in a grazed pasture soil. Aust $J$ Soil Res 42: 927-932.

Di HJ and KC Cameron. 2005. Reducing environmental impacts of agriculture by using a fine particle suspension nitrification inhibitor to decrease nitrate leaching from grazed pastures. Agric Ecosys Environ 109: 202-212.
Di HJ, KC Cameron. 2006. Nitrous oxide emissions from two dairy pastures soils as affected by different rate of fine particle suspension nitrification inhibitor- a lysimeter study. Nutr Cycl Agroeco 79: 281-290

Di HJ, KC Cameron and RR Sherlock. 2007. Comparison of the effectiveness of a nitrification inhibitor, dicyandiamed (DCD), in reducing nitrous oxide emissions in four different soils under different climatic and management conditions. Soil Use Manag 23: 1-9.

Engelen B, K Meinken, F von Winzingerode, $\mathrm{H}$ Heuer, HP Malkomes and H Backhaus. 1998. Monitoring impact of pesticide treatment on bacterial soil communities by metabolic and genetic fingerprint in addition to conventional testing procedures. Appl Environ Microbiol 64: 2814-2821.

Gianfreda L, MA Rao, A Piotrowska, G Palumbo and C Colombo. 2005. Soil enzyme activities as affected by anthropogenic alterations: intensive agricultural practices and organic pollution. Sci Total Environ 341: 265-279.

Hua L, L Xi, Y Chen, G Tian and W Ni. 2008. Effect of nitrification inhibitor DMPP on nitrogen leaching, nitrifying organisms and enzyme activities in a riceoil seed rape cropping system. J Envir Sci 20: 149155.

Irigoyen I, J Muro, M Azpilikueta, A Aparicio-Tejo, and C Lamsfus. 2003. Ammonium oxidation kinetics in the presence of nitrification inhibitors DCD and DMPP at various temperatures. Aust J Soil Res 41: 1177-1183.

Kourtev PS, JG Ehrenfeld and M Haggblom. 2002. Exotic plant species alter the microbial community structure and function in the soil. Ecology 83: 3152-3166.

Linzmeier W, R Guster and U Schmidhalter. 2001. Nitrous oxide emission from soil and from a nitrogen 15-labelled fertilizer with new nitrification inhibitor 3-4 dimethylpyrazole phosphate (DMPP). Biol Fertil Soils 34: 103-108.

Martensson A. 1993. Heterotrophic nitrogen fixation in soil, a method to test chemical impact on biological nitrogen fixation in soil. In: L Torstensson (ed). Soil biological variables in environmental hazard assessment. Guidelines. Swedish Environmental Protection Agency, Stockholm, pp. 91-100.

Mc Carty GW. 1999. Modes of action nitrification inhibitors. Biol Fertil Soils 29: 1-9.

Moir J, KC Cameron and HJ Di. 2007. Effects of the nitrification inhibitor dicyandiamide on soil mineral $\mathrm{N}$, pasture yield, nutrient uptake and pasture quality in a grazed pasture system. Soil Use Manag 23: 111-120.

Pasda GK, G Hanhdel and W Zerulla. 2001. Effect of fertilizers with new nitrification inhibitor DMPP 34 dimethylpyrazole phosphate on yield and quality of agricultural and horticultural crops. Biol Fertil Soils 34: 85-97.

Pell M, B Stenberg and L Torstensson. 1998. Potential denitrification and nitrification tests for evaluation of pesticide effects in soil. Ambiop 37: 24-28. 
Quilchano C and T Maranon. 2002. Dehydrogenase activity in Mediterranean forest soils. Biol Fertil Soils 35: 102-107.

Rasool N and ZA Reshi. 2010. Effect of the fungicide Mancozeb at different application rates on enzyme activities in a silt loam soil of the Kashmir Himalaya, India. Trop Ecol 51(2): 199-205.

Regina K, J Silvova and PJ Martikainen. 1998. Mechanism of $\mathrm{N}_{2} \mathrm{O}$ and $\mathrm{NO}$ production in the soil profile of drained and forested peat land, as studied with acetylene, nitrapyrin and dimethyl ether. Biol Fertil Soils 27: 205 -210.

Richter O, B Diekkrueger and P Noertersheuser. 1996. Environmental fate and modelling of pesticides from laboratory to field scale. VCH Weinheim, New York, pp. 89-93.

Sahrawat KL. 2004. Nitrification inhibitors for controlling methane emission from submerged rice soils. Curr Sci 87: 1084-1087.

Singh SN and A Verma. 2007. The potential of nitrification inhibitors to manage the pollution effect of nitrogen fertilizers in agricultural and other soils: Environ Practice 9: 266-279.
Soil Survey Staff. 1999. Keys to Soil Taxonomy. 8th edi.The United State Department of Agriculture (USDA). Washington DC. 332p

Stephenson GL, N Koper, GF Atkinson, KR Solomon and RP Scroggins. 2000. Use of non linear regression techniques for describing concentration response-relationships of plants species exposed to contaminated site soils. Environ Toxicol Chem 19: 2968-2981.

Stêpniewska Z and A Woliñska. 2005. Soil dehydrogenase activity in the presence of chromium (III) and (VI). Int Agrophys 19: 79-83.

Stêpniewska Z, A Woliñska and R Lipiñska. 2007. Effect of fonofos on soil dehydrogenase activity Int Agrophys 21: 101-105.

Trenkel ME. 1997. Improving fertilizer use efficiency controlled released and stabilized fertilizers in agriculture. Int Fertil Industry Assoc Paris: 151-155.

United States Environmental Protection Agency. 1984. Technical guidance manual for performing waste load allocations. Book II: Stream and Rivers. Chapter 3. Toxic Substances. (EPA 440/4-84-022). United States Environmental Protection Agency, Office of Water. Washington, DC 